Article

\title{
College Campuses and Student Walkability: Assessing the Impact of Smartphone Use on Student Perception and Evaluation of Urban Campus Routes
}

\author{
Joohyun Lee ${ }^{1, *(1)}$ and Mardelle McCuskey Shepley ${ }^{2}$ \\ 1 Sustainability R\&D Center, Chungyeon, Seoul 06248, Korea \\ 2 Department of Design and Environmental Analysis, Cornell University, 1411, Martha Van Rensselaer Hall, \\ 116 Reservoir Ave, Ithaca, NY 14853, USA; mms449@cornell.edu \\ * Correspondence: joohyunlee5@gmail.com; Tel.: +82-10-3283-2154
}

Received: 7 October 2020; Accepted: 26 November 2020; Published: 29 November 2020

check for updates

\begin{abstract}
The purpose of this study is to assess the relationships between college campus walking route characteristics and student perceptions of them with smartphone use. The study used student sketch maps, survey questionnaires, and observations and measurements of route features on a Korean urban campus. The results show that the pedestrian perception and evaluation of campus walking routes are impacted differently in two conditions: walking with smartphone use and walking without smartphone use. "Smartphone walkers" found the safety and quality of routes more important, while walkers without phones considered the shortest distance and positive walking experience to be important factors in their route choices. Campus-built environments need to be improved to provide more adaptive solutions to respond to changes in pedestrian behavior and perception due to increased "smartphone walking". Recommendations include a walker-friendly campus with well-connected streets and networks, separation from vehicles (ensuring safety), good quality sidewalks, and increased campus green space.
\end{abstract}

Keywords: smartphone; walkability; sketch map; user perception; route evaluation; sustainability

\section{Introduction}

This study addresses college student walkers' experiences on an urban college campus in relation to smartphone use and tries to find sustainable design solutions to changes in pedestrian perception and behavior due to "smartphone walking". An urban college campus is an important part of a city as a social, ecological system, and its community members constantly interact with its indoor and outdoor built environment. For instance, college students spend a large portion of their time on campus: attending lectures, studying alone or in groups, relaxing between classes, or participating in dormitory life. To move to the locations of these activities, most students use walking as the green or sustainable mode of transportation on campus. Importantly, today's students are digital natives having grown up with technology. Many of them walk to class wearing headphones, surfing the web on smartphones, and often responding to text messages. Recent surveys indicate that with rising smartphone ownership, smartphone attachment is higher among younger college students than older adults [1]. These young people regularly engage with their phones in a variety of ways while walking $[2,3]$, which results in an increase in pedestrian and phone-related accidents [4-6].

Accordingly, the issue of pedestrian safety with smartphone use has attracted the attention of many researchers. Various studies have reported adaptations or changes in walking gaits when engaging with a smartphone while texting, reading, and talking [4,7-11]. Such phone use causes pedestrians to change the way they walk due to their distracted attention, such as walking slower, 
deviating more from a straight line or frequent direction change, and demonstrating reduced situation awareness [12]. Cell phone use has also impacted pedestrian visual control by creating "in-attentional or inattentive blindness" [7,8].

Walkability takes into account the quality of pathway conditions, security, and comfort for walking [13]. The Walk Score calculates a community walkability rating by identifying the distance to local amenities [14]. One study identified the metrics for the walkability of pedestrian space using criteria such as sidewalk access, street connectivity, land-use density and diversity, safety, and comfort [15]. Previous studies have also shown that there are relationships between the built environment and walking. The specific characteristics of the built environment, such as distance, safety, route condition, and aesthetic qualities correlate most strongly with walking activities [16]. The restorative environment (e.g., greenery and less traffic) led to a decrease in the pedestrians' walking speed while higher traffic intensity and noise made them walk significantly faster $[17,18]$. Minimized distance and safety-related elements (e.g., well-maintained sidewalks and crosswalks) are considered to be a high priority. There is contradictory evidence regarding the impact of pleasant elements (e.g., aesthetics and shade). Some research shows these elements to be a low priority for pedestrians $[19,20]$; other studies report that the pleasantness of walking is an important attribute for route preferences [21,22]. In common, most studies have measured these different environmental conditions, and participants' responses to them, differing in focus from a single attribute in a particular setting to multiple factors in various situations [23-32].

However, many studies on the impact of mobile phone use on walking are limited to laboratory settings, such as walking on a treadmill or through different width doorways with a smartphone [9,33], and do not fully focus on the relationships between the built environment and smartphone walking. Most focus on the smartphone's impact on walking from cognitive and gait perspectives, shown in the studies mentioned earlier. Studying how real-world settings influence dual-tasking pedestrians' awareness of their environments is crucial to understanding their walking behavior. Effective walking is supported by physical environment variables, such as distance, safety, quality, and experience, that enhance walkability and lead to maximum environmental and health benefits. Without the acknowledgment of these benefits and the introduction of features that support these goals, sustainability cannot be achieved. Different types of responses from pedestrians, such as conditioned and subjective responses, need to be measured relative to their perceptions and evaluations of walking routes depending on phone use. In addition, few researchers have exclusively investigated the impact of smartphone use on college student walkability, that is, perceptions of designated routes on campus and how to support good campus walkability for those distracted walkers. In a situation where bans on cell phone use while walking are not realistically practical, assessing the awareness of the physical environment for walkability and designing college campuses that prioritize sustainable and effective walking routes are important to promote successful obstacle/hindrance negotiations necessary for the safe mobility of tech generation students. Most importantly, walking is one of the green transportation modes for a sustainable campus [34], especially in urban areas. Indeed, creating pedestrian-friendly and complete streets on campus is part of several core campus design principles that promote sustainability [35].

Accordingly, the current study addresses two important research questions to fill the gap in the literature: investigating how smartphone use affects walkability and perception related to college student walking-on-campus behaviors; examining students' perceptions of walkability along college campus pedestrian routes and their navigation process of the built environment through avoiding or negotiating obstacles in their way. The questions and hypothesis for this study are as follows:

Question 1: How do students perceive route characteristics when walking with/without smartphones?

Hypothesis 1: If students are walking with smartphones, they will perceive route characteristics differently than those walking without smartphones. 
Question 2: How do students evaluate route characteristics when walking with/without smartphones?

Hypothesis 2: If students are walking with smartphones, they will evaluate route characteristics differently than those walking without smartphones.

\section{Methods}

\subsection{Study Site}

Our study site was a university campus in Daejoen, South Korea. The campus is about $265,000 \mathrm{~m}^{2}$ in size. Unlike many U.S. campuses with thousands of acres, the selected school's campus, located in a suburban area, is not large enough to provide on-campus buses, which makes walking on campus the primary, sustainable, and active travel mode for their students. With more than 8700 students enrolled in five schools and colleges, the campus is bisected by the main library building. The north campus includes 13 buildings, while the south one has 18 buildings, as shown in Figure 1 . The campus ranges in elevation from approximately $103 \mathrm{~m}$ on the north side to $93 \mathrm{~m}$ on the south side. The campus is surrounded by a mountain, golf club, and residential buildings.

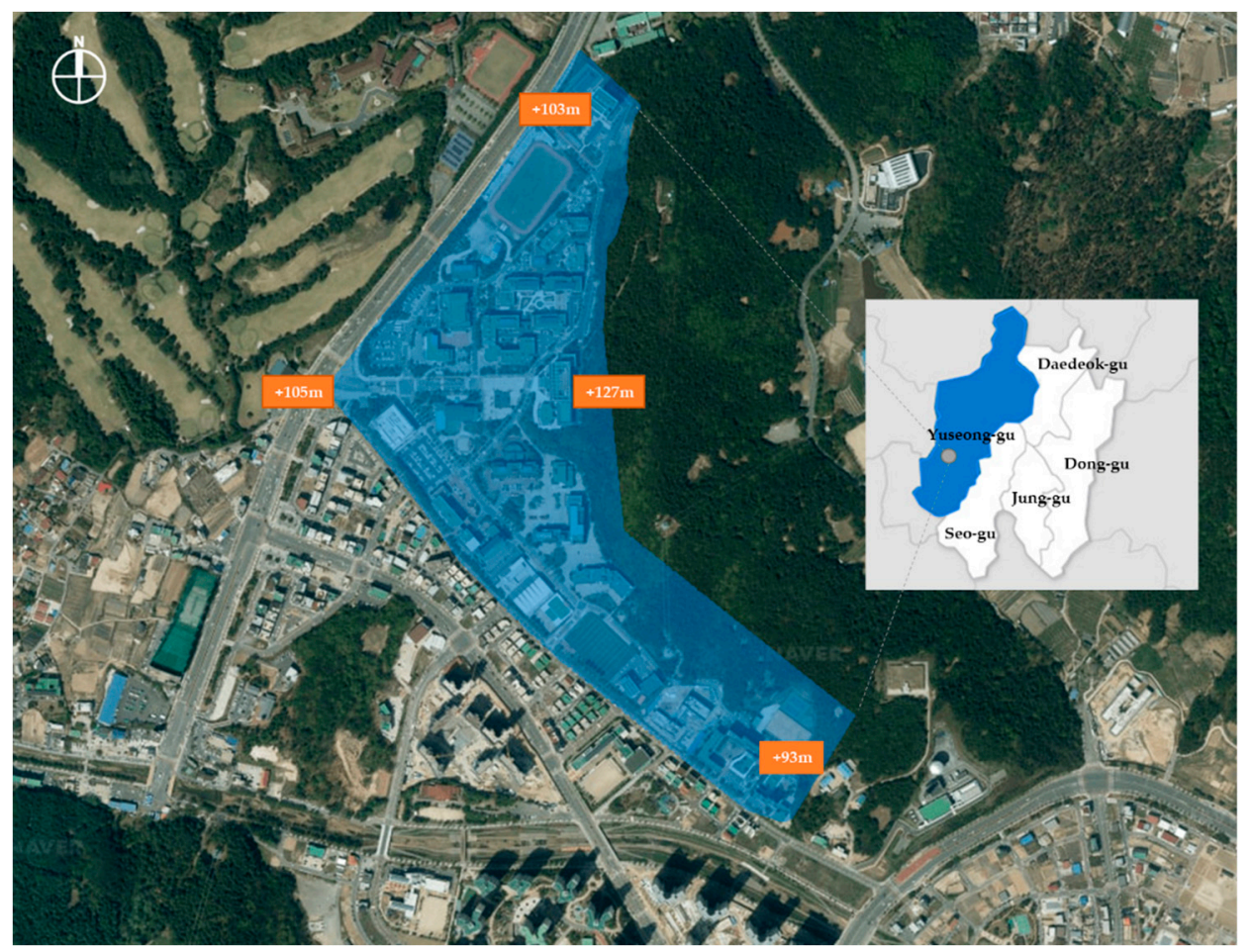

Figure 1. Study site, Daejoen, South Korea.

The data collection of this study was based on the following tools: student sketch maps, questionnaires focusing on student perceptions and evaluations of campus walking routes depending on smartphone use, and direct observations and measurements of walkability conditions on designated routes. The sketch maps were used to find walking routes the students used and to examine their perception of the built environmental features on the chosen campus. A survey questionnaire was used to compare significant differences between students walking without/with smartphones on the campus. Smartphone walkers are defined in this study as those who walk slowly (reading or texting) and pay less attention to their surroundings due to their focus on the smartphone. These individuals typically interacted with their phones rather than periodically glancing at the screen to check for messages. Objective and subjective route attributes, such as distance, safety, sidewalk quality, 
and environmental experience, affect students' walking moderated by their individual differences represented by smartphone use and gender. The observations were conducted to examine the walking route conditions and students' walking minutes. Our data collection methods (sketch maps, surveys, and observation) were a set of useful tools for understanding perception and evaluation of walking routes with/without smartphones and allowed the development of a grounded theory around which a research agenda could be generated. Since our study's main focus was to examine student perception related to smartphone walking, we believe that these methods make a critical contribution to this new area of research. The relationships between the walking route characteristics and student perception and evaluation were statistically analyzed and synthesized by using the Analytical Hierarchy Process (AHP) method to investigate route selection, depending on smartphone use (Figure 2). The methodological triangulation involves using various data collection methods, increasing the credibility and validity of the study by examining the situation from multidimensional viewpoints [36].

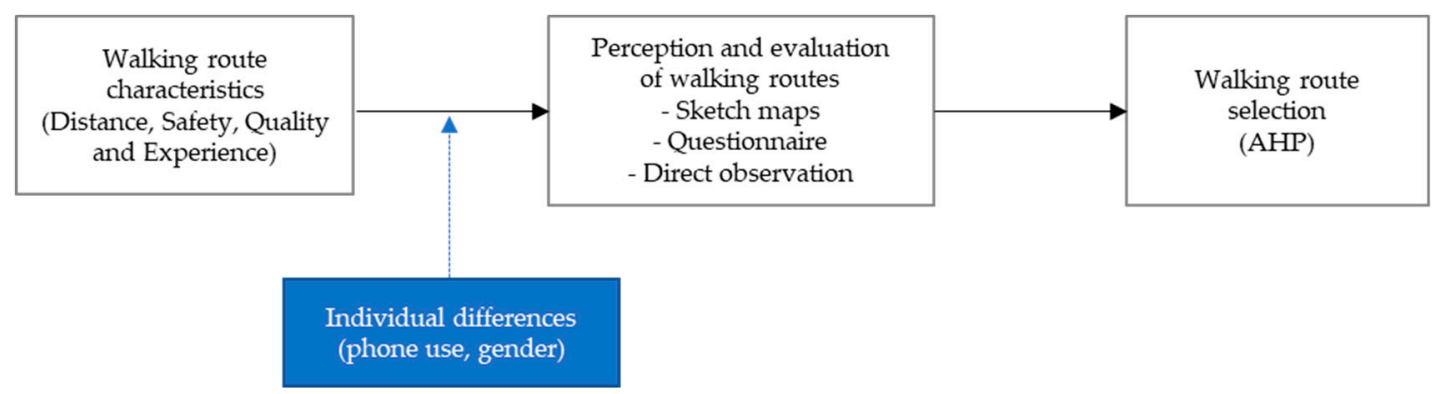

Figure 2. Study framework.

\subsection{Participants}

In the recruitment process, students voluntarily participated in a sketch map drawing and an online survey after accessing a flyer posted on campus bulletins and information distributed on social media. The flyer contained project information (i.e., the aim of the project, a description of what participants will be asked to do, and how long it will take) and the researchers' contact information. Some of the students who had completed the sketch map and survey further agreed to participate in direct observations of their walking behavior. Before the start of each data collection method approved by the KoNIBP (Korea National Institute for Bioethics Policy), participants were given online or printed information and consent forms to read and sign. Figure 3 shows the number of participants in each consecutive investigation: 1—sketch maps, 2-survey questionnaire, and 3-direct observation.

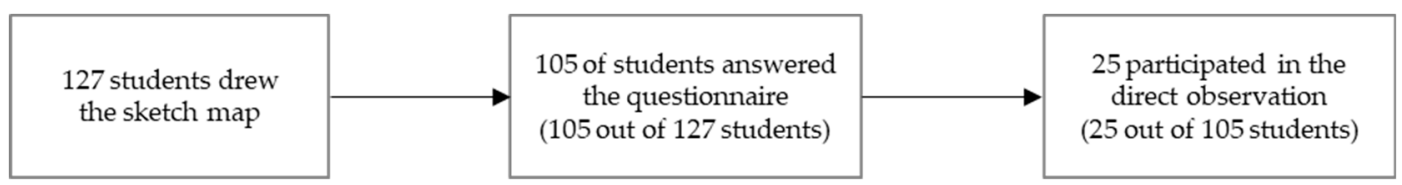

Figure 3. Participated students.

\subsection{Sketch Maps}

For the first investigation, 127 students drew sketch maps with buildings, roads, their walking routes, and other elements on the campus. They noted their gender and phone use while walking. Through these maps, the three most frequently used walking routes were identified (called A, B, and C) between the student center and the main library building. The students participated in drawing sketch maps of the campus areas where their usual walking routes were placed, including as many of the significant physical elements they could remember, such as buildings, roads, sidewalks, trees, and so forth. Sketch maps have been used in previous studies evaluating walking behavior [37-39]. Students drew their maps on a sheet of blank paper with a pencil for $10 \mathrm{~min}$. The focused campus areas were based on the itineraries traveled by the participants around the main libraries and the student center 
where they usually study or work. Although the sketch map method has several concerns regarding the impact of individual differences and the scale and orientation, sketch maps are considered to reflect an unbiased personal understanding of a spatial environment [40]. Sketch maps for this study were used as "mental maps" to help the researchers examine the students' environmental knowledge by the features they drew that they associated with everyday life. The built environment is defined here as "the part of a physical environment that is constructed by human activity" [16], based on basic elements such as paths, edges, districts, nodes, and landmarks [41].

\subsection{Survey Questionnaire}

The survey questionnaire was developed to examine students' perceptions and evaluations of the routes depending on smartphone use (Table 1). A survey is used as one of the important research methods in architecture [36,42,43], urban design, and landscape since it can effectively examine pedestrian perception on walking routes and the built environment $[20,29]$. The survey sample included a total of 105 full-time students on the chosen campus. 52 of them were male; 53 were female. We sought to measure and quantify the extent to which the students' perception and evaluation of walking routes might differ depending on walking with/without phone use. The students were asked a total of six questions in multiple-choice and 5-point Likert Scales (interval scales from "not at all important" to "extremely important"). We asked the participants to evaluate the route characteristics according to their perception in terms of distance, safety, quality, and experience. The questions were about the following issues: walking while using a smartphone or not, their perception on walking route characteristics depending on mobile phone use, use frequency of walking Routes A, B, and C, and evaluation of each route. We identified walking route features to consider from previous research studies that had found significant built environmental features that influence walking. Additionally, the Leadership in Energy and Environmental Design for Neighborhood Development (LEED-ND) design guidelines also provided walkability measures from the perspective of architecture and urban design to encourage walking by providing safe, appealing, and comfortable neighborhood environments [44]. Finally, walking route elements were identified as essential factors related to walking route perception and evaluation, and were put into four categories for this research: distance, safety, quality, and experience. "Distance" indicated a physical length to a destination: a direct and logical route. "Safety" concerns about sidewalk conditions affected the pedestrians' perceived traffic safety and was alleviated by vehicle-free areas and pedestrian-friendly sidewalks. "Quality" referred to sidewalk quality, including continuous sidewalks and even pavement. "Experience" meant interesting features and activities (e.g., water elements, vegetation, such as trees and grass), and items to see at eye level which contributed to pleasure in walking (people sitting on a bench, singing and playing guitar, and boomerang throwers). The route was divided into three courses with different environmental features. In addition, subjects provided their gender to allow for the investigation of interactions between gender and phone use. Smartphone use while ambulating was expected to affect the participants' perception and evaluation of walking routes on the university campus.

\subsection{Direct Observations}

Participants were asked to walk along the routes on the campus. 25 students $(23.1 \%$ of the survey participants) walked from the student center to the main library building taking Routes A, B, or C. The completion of each walking route took about 10-20 $\mathrm{min}$ in two conditions: with and without a smartphone. In the process, their walking behaviors were observed and noted by the principal investigator. Several researchers have conducted direct observations to compare predicted patterns of how people actually use space with actual behavior $[17,45,46]$. This empirical method can provide researchers with direct experience and understanding of spaces [42,43]. Direct observations and measurements of route conditions in relation to walkability also provided detailed information on walking experience and routes. We recorded the movements and interactions of voluntary student walkers with the built environment on a site plan with a pencil, following the walkers. Two observers 
tracked 25 subjects ( $30 \%$ of the survey participants) separately from the origin to the destination within 10-min walking times on Routes A, B, and C. The students' walking distances and walking times were measured using an activity application on a smartphone.

Table 1. Survey questionnaire.

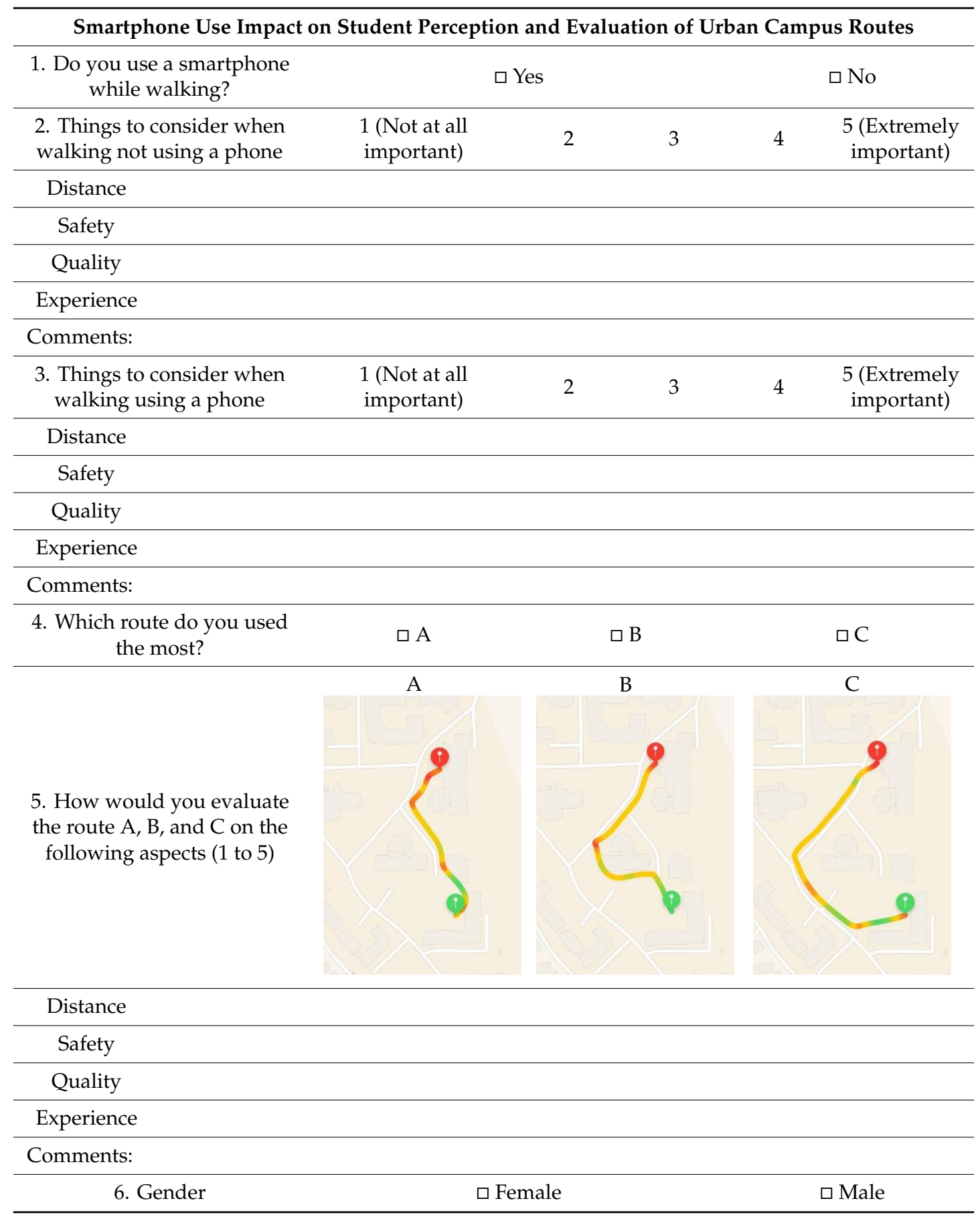

\subsection{Data Analysis}

For the statistical analysis, the collected data sets from the surveys were transferred to electronic files using SPSS. The input was then double-checked by the researchers to confirm consistency between the electronic files and the original data. For the perception and evaluation survey data, the score of the scale ranged from 1 to 5 . Descriptive statistics of all variables were made to describe the data. ANOVA 
was used to test interaction effects between smartphone use and gender to see whether the means of groups were significantly different or not. The Wilcoxon test compared two conditions when the same participant had taken part in each condition (walking without/with phones); it was performed to find differences in students' perceptions of walking route characteristics depending on smartphone use. Friedman's ANOVA was used in the process to find differences in the students' evaluations of three walking route characteristics. The study also used the AHP method to examine student perceptions and evaluations of walking route attributes, depending on phone use by importance priority and weight. The AHP is a widely used multi-criteria decision-making method using a pair-wise comparison and ratio/scale priorities to identify and rate the importance by comparing elements involved in a decision [47]. The triangulation of the sources of evidence in this study helped yield a more thorough empirical inquiry into a contemporary phenomenon within its real-life context [36,48].

\section{Results}

\subsection{Walking Route Sketch Maps}

By gathering and analyzing the sketch maps, we found some common walking routes the students used on a regular basis, and the images of their routes showed campus-built environmental features perceived by them. The present study endeavored to elicit information from the sketch maps by breaking them up into smaller units with significant landmarks or pedestrian routes, which yielded three main routes from the student center to the main library on the selected college campus: Routes A, B, and C. As an example, sketch maps by the students for the research are presented in Table 2. Depending on the degree of detail, the students drew simple and less sophisticated maps to more accurate and sophisticated maps, with multiple labels, street networks, buildings of a variety of proportions, landscapes, and other built forms of the campus as well.

A total of 127 students drew 5 to 10 buildings, on average, in their sketch maps and networks of roads and walkways along with their walking routes. About one-third of the students (42 students) in the survey completed the sketch maps by including natural elements of trees, green spaces, and ponds. Two-thirds (85 students) sketched only built environmental features, such as buildings, roads, sidewalks, and parking lots. In addition, the sketch map descriptions of the students who were smartphone walkers (89 students) were generally brief and less sophisticated, but those without phones while walking (38 students) were able to draw better, more sophisticated sketch maps with more specific details according to their spatial memories.

\subsection{Surveyed Student Characteristics}

A total of 105 questionnaire responses were received and analyzed: 52 male and 53 female students. The vast majority, $79.0 \%$ of the participants, answered that they regularly engage with their smartphones while walking, as shown in Table 3. Conversely, $21.0 \%$ of the respondents walk without phone use. Furthermore, $71.2 \%$ of male and $86.8 \%$ of female respondents walk on the chosen campus with phone use; the phone use of the female students is slightly higher compared with that of the male students.

\subsection{The Student Perception of Walking Route Characteristics Depending on Phone Use}

The students were asked to identify and rate the perceived importance of different walking route characteristics depending on phone use: distance, safety, quality, and experience, as shown in Table 4. The students walking without phones gave higher levels of importance to "distance" compared with those with phones $(p=0.026)$. The students walking with phones also reported that they consider distance in their walking since they know using phones while walking slows their walking speed, which encourages them to choose a shorter route. For the students walking with phones, "safety" is significantly more important as well, compared with those walking without phones $(p=0.001)$. For them, it is difficult to check things above their eye level while focusing on their phone screen with 
the head down. The results of the "quality" measure found the difference to be significant $(p=0.000)$. The students without phones showed significantly less perceived importance of this category compared with the smartphone walkers. On the other hand, the students who had distracted walking due to smartphone use perceived more importance of the quality of the walking route. These differences indicate that the presence of sidewalks and the quality of pavement/surfaces play an important role in enhancing walking comfort.

Table 2. Samples of student sketch maps.

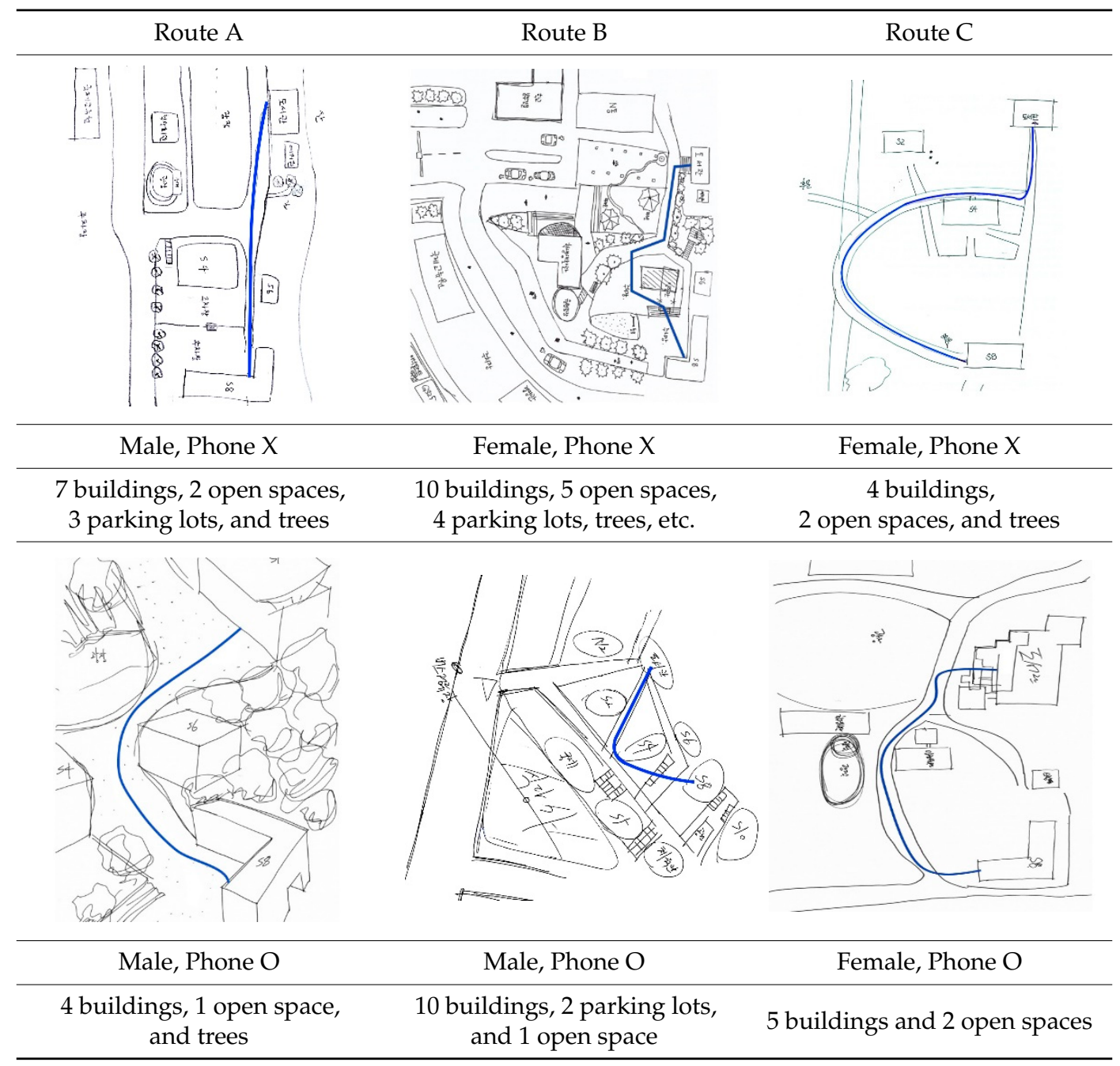

Table 3. Characteristics of respondents $(n=105)$.

\begin{tabular}{cccc}
\hline Gender & $\begin{array}{c}\text { Walking } \\
\text { without Phones }\end{array}$ & $\begin{array}{c}\text { Walking } \\
\text { with Phones }\end{array}$ & Total \\
\hline Female & $7(6.7 \%)$ & $46(42.8 \%)$ & $53(50.5 \%)$ \\
\hline Male & $15(14.3 \%)$ & $37(35.2 \%)$ & $52(49.5 \%)$ \\
\hline Total & $22(21.0 \%)$ & $83(79.0 \%)$ & $105(100.0 \%)$ \\
\hline
\end{tabular}


Table 4. Student perception ratings of walking route characteristics depending on phone use.

\begin{tabular}{|c|c|c|c|c|}
\hline \multicolumn{2}{|c|}{ Outcome Measure } & $\begin{array}{l}\text { Walking } \\
\text { without Phones (a) }\end{array}$ & $\begin{array}{c}\text { Walking } \\
\text { with Phones (b) }\end{array}$ & $\begin{array}{l}\text { Wilcoxon Test } \\
\text { Sig. (2-Tailed) }\end{array}$ \\
\hline \multirow{2}{*}{ Distance } & Mean & 3.70 & 3.38 & \multirow{2}{*}{$a>b, 0.026$} \\
\hline & Std. & 1.23 & 1.27 & \\
\hline \multirow{2}{*}{ Safety } & Mean & 3.83 & 4.25 & \multirow{2}{*}{$\mathrm{a}<\mathrm{b}, 0.001$} \\
\hline & Std. & 1.25 & 1.15 & \\
\hline \multirow{2}{*}{ Quality } & Mean & 3.36 & 3.85 & \multirow{2}{*}{$\mathrm{a}<\mathrm{b}, 0.000$} \\
\hline & Std. & 1.14 & 1.25 & \\
\hline \multirow{2}{*}{ Experience } & Mean & 2.98 & 2.31 & \multirow{2}{*}{$a>b, 0.000$} \\
\hline & Std. & 1.39 & 1.36 & \\
\hline
\end{tabular}

Note: The results of two analyses are consolidated in this table. $p$ Values are expressed in 3 digits. Wilcoxon signed-rank test, two-sided.

The students with phones reported that they need continuous, wide, and pedestrian-only paths. The route used for their walking was related to better path infrastructure, being well connected in the sidewalk network, and having specific destinations along them. For experience, there was a statistically significant difference in the students' perception of routes, depending on phone use $(p=0.000)$. Both students preferred to walk in the shade, but their reasons were different. The students without phones seemed to have more enjoyable walking experiences due to trees and landscaping. Others with phones chose to walk in the shade to prevent the cell phone screen from reflecting the sun.

The student walkers without phones rated distance and experience as important factors when choosing their walking routes on campus and walkers with phones considered safety and quality more important for their walking routes (Figure 4). Despite these differences, both of the groups showed a tendency to choose the shortest or fastest route for their walking on campus. This fact indicates that the quick goal-oriented walk from one place to another, along with direct and short routes between places, are the most common reasons for choosing their routes.

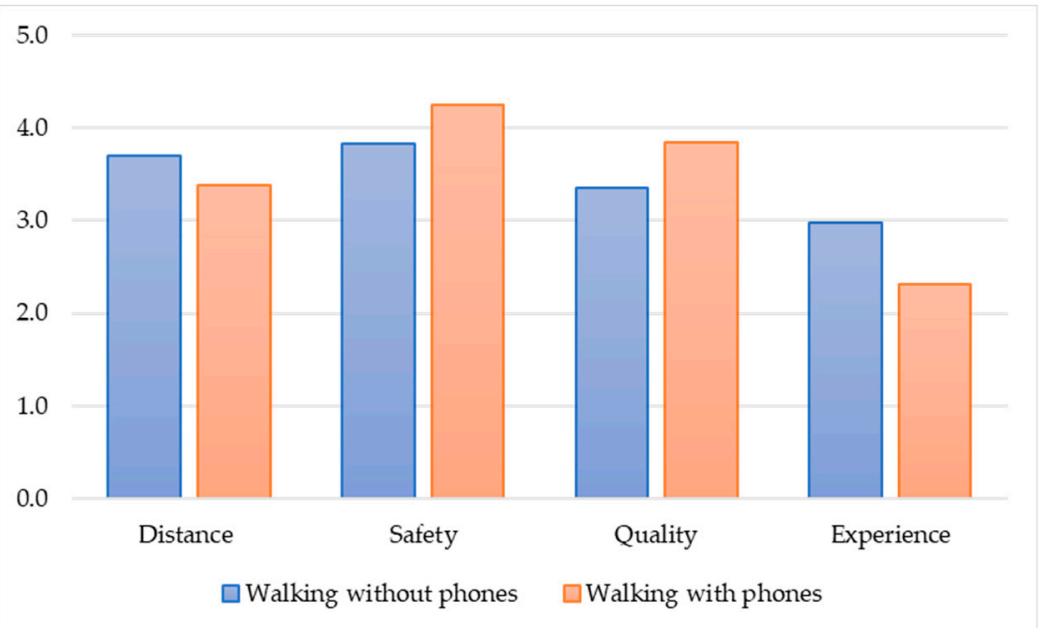

Figure 4. Student perception ratings of walking route characteristics depending on phone use.

Another interesting factor relating to the participants' route choice is the experience they have while walking, such as interesting walking features and attractive views of walking routes. The smartphone walkers were less attentive to views along the route and its surroundings. According to the comments by the participants in the survey, the students without smartphones had a tendency to walk more for 
recreational purposes compared with those with phones. Figure 4 shows that the smartphone walkers were less attentive to views along the route and its surroundings.

\subsection{The Interaction between Phone Use and Gender}

In addition, we looked for gender effects of with/without smartphone conditions, as shown in Table 5. Ratings from the male and female participants were similar $(p>0.05)$. Gender did not significantly interact with phone use, as other studies have shown $[6,15]$.

Table 5. The interaction between phone use and gender.

\begin{tabular}{ccccccc}
\hline \multicolumn{7}{c}{ Tests of Between-Subjects Effects (Phone x Gender) } \\
\hline $\begin{array}{c}\text { Walking Route } \\
\text { Characteristic }\end{array}$ & $\begin{array}{c}\text { Type III Sum } \\
\text { of Squares }\end{array}$ & $\mathbf{d f}$ & Mean Square & $\mathbf{F}$ & Sig. & Partial Eta Squared \\
\hline Distance & 0.437 & 1 & 0.437 & 0.276 & 0.600 & 0.002 \\
\hline Safety & 1.567 & 1 & 1.567 & 1.081 & 0.300 & 0.007 \\
\hline Quality & 0.351 & 1 & 0.351 & 0.243 & 0.623 & 0.002 \\
\hline Experience & 0.705 & 1 & 0.705 & 0.372 & 0.543 & 0.002 \\
\hline
\end{tabular}

Note: Degrees of freedom (df). F-values (F).

\subsection{Student Evaluation of Walking Route Characteristics}

The participants were also asked to evaluate the characteristics of walking Routes A, B, or C in terms of distance, safety, quality, and experience. Friedman's test was used to test differences among the three routes, and the students gave scores in all the walking route characteristics, as shown in Table 6. For distance, we concluded that the student evaluations are significantly different among Routes A, B, and C $(p=0.000)$. For safety, there is a significant difference across the three routes $(\mathrm{x} 2(2)=7.65, p=0.021)$. Additionally, the evaluations of route quality significantly differ among Routes A, B, and C (x2 (2) = 89.43, $p=0.00)$. Lastly, for the category of experience, the results show differences between the three routes $(\times 2(2)=52.80, p=0.000)$. We can conclude that the students differently evaluated the characteristics of walking Routes $A, B$, and $C$ : distance $(A>C>B)$, safety $(C>A>B)$, quality $(C>B>A)$, and experience $(C>A>B)$, as shown in Figure 5.

Table 6. Student evaluation of walking route characteristics.

\begin{tabular}{|c|c|c|c|c|c|c|c|}
\hline \multirow{2}{*}{\multicolumn{2}{|c|}{ Outcome Measure }} & \multirow[b]{2}{*}{ Route A } & \multirow[b]{2}{*}{ Route B } & \multirow[b]{2}{*}{ Route C } & \multicolumn{3}{|c|}{ Friedman's ANOVA } \\
\hline & & & & & $\begin{array}{c}\mathrm{T} \\
\text { (Chi-Square) }\end{array}$ & df & $\begin{array}{c}\text { Sig. } \\
\text { (2-Tailed) }\end{array}$ \\
\hline \multirow{2}{*}{ Distance } & Mean & 4.59 & 2.49 & 2.72 & \multirow{2}{*}{98.64} & \multirow{2}{*}{2} & \multirow{2}{*}{$\begin{array}{c}0.000 \\
A>C>B\end{array}$} \\
\hline & Std. & 0.99 & 0.50 & 1.04 & & & \\
\hline \multirow{2}{*}{ Safety } & Mean & 3.21 & 3.10 & 3.81 & \multirow{2}{*}{7.65} & \multirow{2}{*}{2} & \multirow{2}{*}{$\begin{array}{c}0.021 \\
C>A>B\end{array}$} \\
\hline & Std. & 1.29 & 1.19 & 1.05 & & & \\
\hline \multirow{2}{*}{ Quality } & Mean & 2.14 & 2.67 & 3.62 & \multirow{2}{*}{89.43} & \multirow{2}{*}{2} & \multirow{2}{*}{$\begin{array}{c}0.000 \\
C>B>A\end{array}$} \\
\hline & Std. & 1.00 & 1.17 & 0.97 & & & \\
\hline \multirow{2}{*}{ Experience } & Mean & 2.89 & 2.68 & 3.93 & \multirow{2}{*}{52.80} & \multirow{2}{*}{2} & \multirow{2}{*}{$\begin{array}{c}0.000 \\
C>A>B\end{array}$} \\
\hline & Std. & 1.17 & 1.04 & 1.02 & & & \\
\hline
\end{tabular}

Note: The results of two analyses are consolidated in this table. $p$ Values are expressed in 3 digits. Standard Deviation (Std.). Friedman's ANOVA, two-sided. 


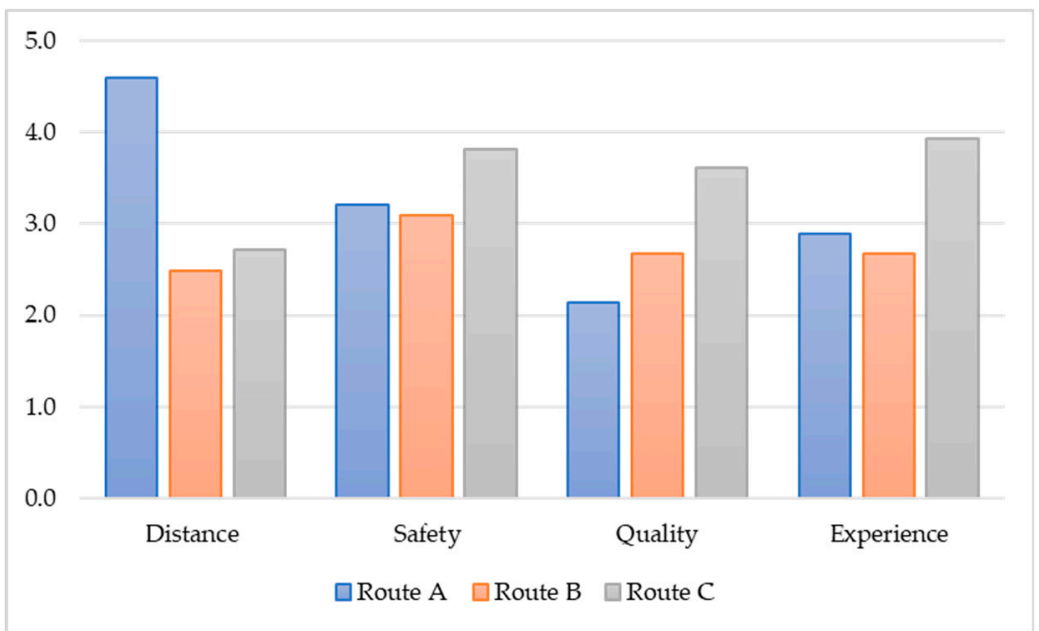

Figure 5. Students' evaluation of route characteristics.

\subsection{The Frequency of Walking Route Use}

As shown in Table 7, the 105 participants responded to the frequency of use of walking routes in the order of A (54.2\%), C (33.3\%), and B (12.5\%). A was the shortest walking distance while C was the longest one. Some of the students commented that Route B has slopes and stairs that make it hard to walk, so they prefer Route C.

Table 7. Frequency of route use.

\begin{tabular}{ccccc}
\hline & A & B & C & Total \\
\hline Frequency of walking route use & $44(54.2 \%)$ & $10(12.5 \%)$ & $27(33.3 \%)$ & $105(100.0 \%)$ \\
\hline
\end{tabular}

\subsection{The Direct Observation of Walking Routes A, B, and C}

Table 8 illustrates the results of the direct observations. It includes straight line distances on the map and walking distances in reality, detour ratios, and walking time with/without phones. The detour ratio was determined by dividing the walking distance by the straight line distance from the origin (student center) to the destination (library).

The results indicate that a large ratio means that the students had to walk a longer distance over a longer time, in the order of Routes C, B, and A. The lengths of walking distances varied from 240 to $560 \mathrm{~m}$. If the students considered the shortest distance as the most important factor when choosing the walking paths, they would choose Route A, B, and C in sequence. Stairs and slopes were physical and psychological challenges for the pedestrians, especially for the smartphone walkers. The students found walking up stairs and slopes harder than walking on the flat ground, and they avoided these barriers whenever they could, especially with smartphones. Though the walking distance was shorter, the routes had more obstacles, such as driveways, stairs, slopes, and parking lots. These obstacles tended to not only hinder walking but also cause safety problems, especially for smartphone users.

\subsection{Walking Route Selection Analysis by Analytical Hierarchy Process}

The Analytical Hierarchy Process (AHP) was applied to find the most suitable route based on the students' perception and evaluation of their routes. Walking route selection is a complex process that has important outcomes for understanding the relationships between student perception and route characteristics. The factors affecting both student perception and evaluation in selecting walking routes are given in two hierarchies below (Figure 6). 
Table 8. Walking Routes, A, B, C.

\begin{tabular}{|c|c|c|c|}
\hline & Route A & Route B & Route C \\
\hline Maps & & & \\
\hline Straight line distance $(\mathrm{m})$ & 223 & 223 & 223 \\
\hline Walking distance $(\mathrm{m})$ & 240 & 280 & 560 \\
\hline $\begin{array}{l}\text { Detour ratio } \\
\frac{\text { Walking }}{\text { Straight line }}\end{array}$ & 1.08 & 1.25 & 2.51 \\
\hline $\begin{array}{l}\text { Walking time without } \\
\text { phones (Mean) }\end{array}$ & $3^{\prime} 45^{\prime \prime}$ & $4^{\prime} 20^{\prime \prime}$ & $6^{\prime} 44^{\prime \prime}$ \\
\hline $\begin{array}{l}\text { Walking time with } \\
\text { phones (Mean) }\end{array}$ & $9^{\prime} 36^{\prime \prime}$ & $15^{\prime} 12^{\prime \prime}$ & $22^{\prime} 24^{\prime \prime}$ \\
\hline Slope and stair & Upper slope & $\begin{array}{l}\text { Mid slope, Two } \\
\text { stairways }\end{array}$ & Lower slope \\
\hline
\end{tabular}

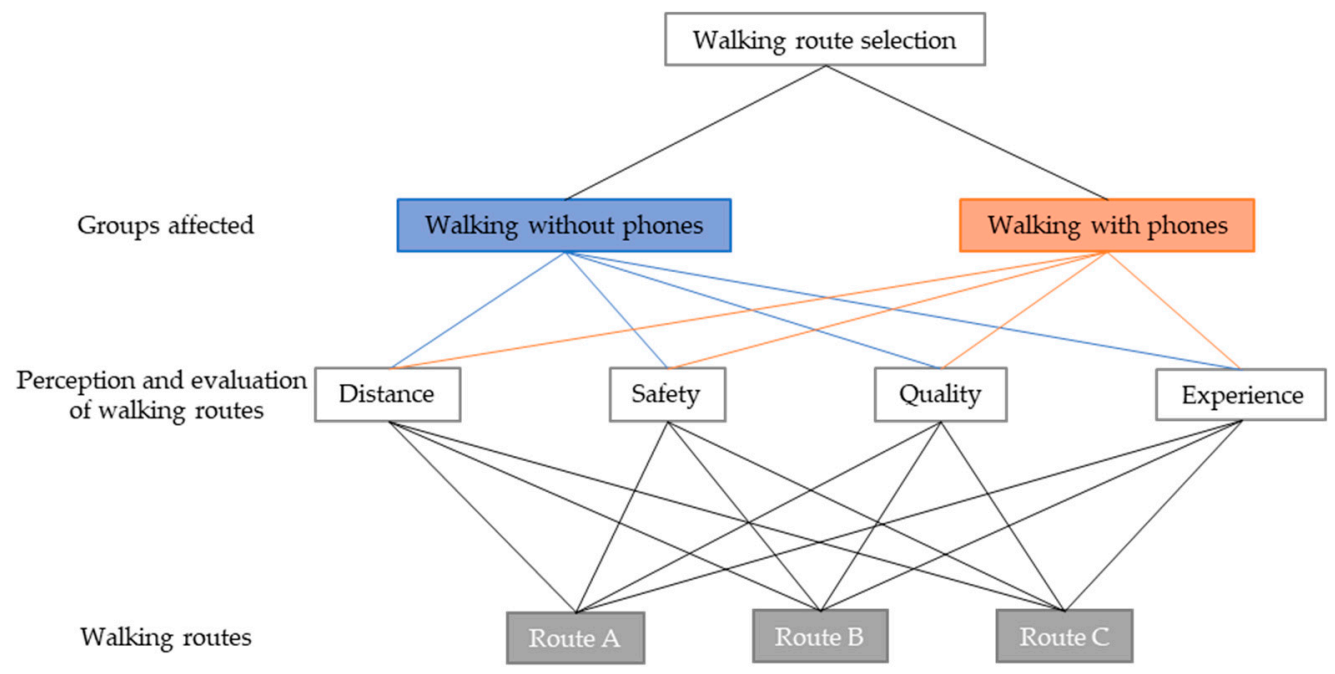

Figure 6. Hierarchy for choosing walking routes.

Based on the previous results from the students' perceptions on distance, safety, quality, and experience, and evaluations of Routes A, B, C, we obtained the numbers of relative weight, as shown in Table 9. Regarding the perceived importance of route factors, distance $(0.267>0.245)$ and experience $(0.215>0.168)$ were higher priorities for the students walking without phones compared with those walking with phones. When comparing safety $(0.276<0.308)$ and quality $(0.242<0.279)$ weights, the students walking with phones perceived them to be more important than those walking without phones. 
Table 9. Student perception and evaluation of walking route characteristics by AHP.

\begin{tabular}{ccccc}
\hline \multirow{2}{*}{ Perception } & \multicolumn{2}{c}{ Walking without Phones } & \multicolumn{2}{c}{ Walking with Phones } \\
\cline { 2 - 5 } & Priority & Rank & Priority & Rank \\
\hline Distance & 0.267 & 2 & 0.245 & 3 \\
\hline Safety & 0.276 & 1 & 0.308 & 1 \\
\hline Quality & 0.242 & 3 & 0.279 & 2 \\
\hline Experience & 0.215 & 4 & 0.168 & 4 \\
\hline Evaluation & Distance & Safety & Quality & Experience \\
\hline A & 0.464 & 0.317 & 0.250 & 0.305 \\
\hline B & 0.258 & 0.307 & 0.321 & 0.284 \\
\hline C & 0.278 & 0.376 & 0.429 & 0.411 \\
\hline
\end{tabular}

As far as safety was concerned, separation from vehicles was perceived to be the most important factor in the students' route selection, regardless of phone use. To the students walking without phones, distance was slightly more important than quality or experience. For the students walking with phones, quality was the second most important factor in their route selections. For both groups of students, experience was the least important consideration regarding walking route characteristics. The next step was to compare Routes A, B, and C with respect to student evaluations of route factors according to distance, safety, quality, and experience.

This calculation gives a final priority of 0.369 for Route C (safety, sidewalk quality, and good walking experience), which was the most preferred route for those students walking on the campus. Route A (shortest distance) was found to be the second most preferred one with a priority of 0.339 (Table 10). This finding indicates that the students used walking not only as an instrumental tool to move from place to place but also as a recreational activity. Route B had the lowest priorities for distance, safety, and experience, but not for quality. Route B was less interesting for the students and had safety concerns, such as stairs, levels, and cutting through parking lots.

To synthesize the overall priority scale, we multiplied them as follows:

Table 10. AHP Calculations.

\begin{tabular}{|c|c|c|c|c|c|c|c|c|}
\hline & Route & Perception & & Eval & uation & & & Sum \\
\hline $\begin{array}{l}\text { Walking } \\
\text { without } \\
\text { phones }\end{array}$ & $\begin{array}{l}\text { A } \\
\text { B } \\
\text { C }\end{array}$ & $\left.\begin{array}{l}0.267 \\
0.276 \\
0.242 \\
0.215\end{array}\right)$ & $\begin{array}{c}\text { Distance } \\
0.464 \\
0.258 \\
0.278\end{array}$ & $\begin{array}{c}\text { Safety } \\
0.317 \\
0.307 \\
0.376\end{array}$ & $\begin{array}{c}\text { Quality } \\
0.250 \\
0.321 \\
0.429\end{array}$ & $\begin{array}{c}\text { Experience } \\
0.305 \\
0.284 \\
0.411\end{array}$ & $=$ & $\begin{array}{l}0.339 \\
0.292 \\
0.369\end{array}$ \\
\hline $\begin{array}{l}\text { Walking } \\
\text { with } \\
\text { phones }\end{array}$ & $\begin{array}{l}\text { A } \\
\text { B } \\
\text { C }\end{array}$ & $\begin{array}{l}0.245 \\
0.308 \\
0.279 \\
0.168\end{array}$ & $\begin{array}{c}\text { Distance } \\
0.464 \\
0.258 \\
0.278\end{array}$ & $\begin{array}{c}\text { Safety } \\
0.317 \\
0.307 \\
0.376\end{array}$ & $\begin{array}{c}\text { Quality } \\
0.250 \\
0.321 \\
0.429\end{array}$ & $\begin{array}{c}\text { Experience } \\
0.305 \\
0.284 \\
0.411\end{array}$ & $=$ & $\begin{array}{l}0.334 \\
0.294 \\
0.372\end{array}$ \\
\hline
\end{tabular}

Note: Walking without phones and Route $C=0.267 \times 0.278+0.276 \times 0.376+0.242 \times 0.429+0.215 \times 0.411=0.369$.

The differences in students' perception of the walking route characteristics according to phone use and the evaluation of the three routes' characteristics were used to determine which route was the most preferred route for student walking. However, in reality, when asked about the frequency of use of the walking routes, the students used A $(54.2 \%)$, B (12.5\%), and C (33.3\%) respectively (Table 7). This result shows that there is a difference in the students' perception of the characteristics of the walkway and their choice of actual walkway. Other researchers (e.g., $[49,50])$ have found this as well. 


\section{Discussion}

By coupling student surveys with sketch maps and direct observations of the walking routes on campus, this study was able to find walking route components related to user perception and evaluation, which influenced their choice of routes. The sketch maps particularly helped us to assess the students' spatial memory about their usual walking routes on campus. The results demonstrate that walking is a complex behavior and various factors affect pedestrians' walking experiences and route choices. For instance, the participating students considered safety as the most important factor when walking without/with smartphones on campus. Particularly, the students with smartphones walked more slowly and frequently experienced uncertainty in deciding whether to cross traffic, wait when they tried to cross a street to reach the student center building, or cut through a parking lot to their destination. Their walking often changed in speed and directions due to these difficulties. Distance was the second primary consideration when choosing a route for their walking. Since a majority of surveyed students usually walk with phones on campus, the safety issue concerns them the most. Other factors affecting walking routes are sidewalk quality and attractiveness. The study results suggest that design professionals should encourage walking by focusing on creating walking routes on campus where students feel safe, can comfortably cross the street, and can walk to places with direct and well-connected routes. Experience is also important for other reasons, such as supporting and encouraging more pleasant and recreational walking paths, which promote student physical activity, wellbeing, and campus sustainability.

In particular, the students' choices of the shortest or fastest routes for their walking on campus shows that the participants followed some general assumptions about walking route choice. For example, walking is a linear movement as a form of transportation that brings the walker from the origin to the destination [51]. Directness is the most important reason for choosing a particular route [24,49]. Continuous paths in time and space are also significant in pedestrians' route choices [52]. This study's findings also coincide with those of other studies showing phone use negatively affects walking due to pedestrians' impaired visual and auditory attention [33]. Based on this statistical analysis, a growing number of pedestrians walking with phones and their different perceptions of the walking environment should be considered to improve safety and route quality.

For those students who are not smartphone walkers, visual and other types of attractiveness played significant roles in their route selection. When walkers find interest in their routes, they are more willing to accept a considerably longer walk. When they feel bored with their routes, their walking drops drastically [51]. However, the students with smartphones reported that they had not taken the landscape into consideration when choosing a route. This shows that smartphone use affects the students' route choice while interacting with other factors.

\section{Conclusions}

Walking has benefits for personal health and environmental sustainability; a walkable neighborhood can lead to the sustainability of a place [53] and better health outcomes [54]. Providing walkable built environments and increasing walking behavior could reduce greenhouse gases and other pollutants by reducing people's need for vehicles and improving their physical activities for health and wellbeing. However, walking has recently become more difficult and far less attractive, due to more vehicle-dedicated spaces and amenities such as signs, parking lots, street lamps, and other obstacles [51]. Most university campuses are also designed with roads centering on vehicle traffic, and not focusing on pedestrians.

This study provides a framework for understanding how walking route characteristics can be perceived and evaluated by young pedestrians, especially, with smartphone use. It is important to understand not only route characteristics but also how students perceive and evaluate routes and their route segments on campus when designing a campus to support walking. Today's digitally native students have different walking behavior patterns and different perceptions of their built environments. The issue of campus walkability needs to focus on providing such students with opportunities for more 
walking with guaranteed safety. The provision of sidewalks and marked crosswalks are suggested for pedestrian use for safe walking routes.

As a reduction in cellphone use is not likely, colleges must address walking safety on their campuses and consider the design goal of improving mental health and wellbeing by enhancing the walking experience. Removing physical and psychological obstacles to walking on campus could be the first step in the process by ensuring quality walking routes. For example, the Seoul Metropolitan Government has posted "No smartphone use while walking" signs to warn smartphone walkers and encourage road safety around densely populated and accident-prone areas: City Hall, the Gangnam and Jamsil subway stations, Yonsei University, and Hongik University (Figure 7). Out of these, 250 are circular signs plastered on pavements. The other 50 are triangular signs attached to lamp posts or traffic light posts [55].

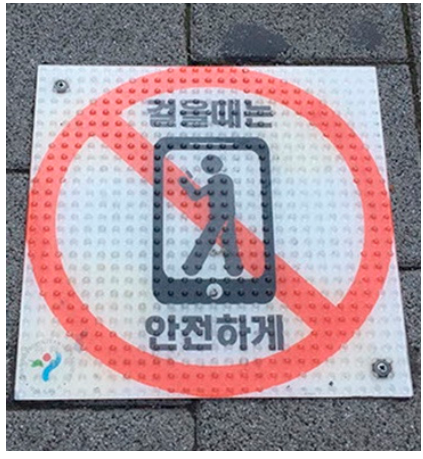

(a)

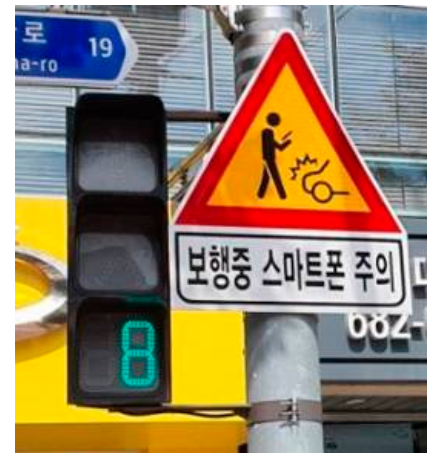

(b)

Figure 7. Street signs. (a) Walk Safely; (b) Warning: Using Smartphone While Walking.

Quality can be achieved through multiple design elements, including reduced scale and access to nature. Small-sized blocks and buildings connected with paths through which students pass with more ease support walker-friendly networks compared with massive buildings with limited entrances and passages blocking continuous movement or flow of walkers. Particularly, buildings configured in a circular formation encourage student walkers to move quickly, engaging in more physical activity [35]. Making spaces inviting with many units and doors is advantageous because it provides opportunities for better interaction.

Regarding access to nature, creating more effective visual links between interior and exterior spaces may also motivate student walkers to engage in more physical activity. We believe that more opportunities for recreational walking will result in less instrumental walking, and improved health and stress reduction.

Planning and designing campus buildings and walking routes should involve users to meet campus pedestrian needs [56]. When constructing campus-built environments, contemporary decision-makers and professionals need to pay attention to changes in the way students use and perceive buildings as a result of new personal technological devices.

The study sample focused on a single context with a small number of participants and could not fully control all of the variables related to students' walking with/without phones in real conditions (i.e., traffic density and weather conditions). Despite this limitation, the findings of this research on campus walkability and student smartphone use while walking will be of practical value for other colleges with similar built environments. Simultaneous testing in several environments with diverse populations can yield more generalizable, reliable, and insightful conclusions, and better ascertain a variety of student needs on different campuses to make more vibrant communities for long-term institutional health and sustainability. Walking is associated with a broad range of healthful psychological, physical, and social factors. A comprehensive examination of these factors is recommended for a deeper understanding of the relationships between built environments and walkers. 
Author Contributions: Conceptualization, J.L.; methodology, J.L. and M.M.S.; formal analysis, J.L.; investigation, J.L.; writing — original draft preparation, J.L.; writing—review and editing, M.M.S.; Discussion, J.L. and M.M.S. All authors have read and agreed to the published version of the manuscript.

Funding: This research received no external funding.

Conflicts of Interest: The authors declare no conflict of interest.

\section{References}

1. Saad, L. Nearly Half of Smartphone Users Can't Imagine Life Without It. Available online: http://news.gallup. com/poll/184085/nearly-half-smartphone-users-imagine-life-without.aspx (accessed on 13 December 2018).

2. Horrigan, J.B. Mobile Access to Data and Information. Available online: http://www.pewinternet.org/2008/ 03/05/mobile-access-to-data-and-information-2/ (accessed on 19 December 2018).

3. Thornton, B.; Faires, A.; Robbins, M.; Rollins, E. The mere presence of a cell phone may be distracting implications for attention and task performance. Soc. Psychol. 2014, 45, 479-488. [CrossRef]

4. Nasar, J.L.; Troyer, D. Pedestrian injuries due to mobile phone use in public places. Accid. Anal. Prev. 2013, 57, 91-95. [CrossRef]

5. Timmis, M.A.; Bijl, H.; Turner, K.; Basevitch, I.; Taylor, M.J.D.; Paridon, K.N.V. The impact of mobile phone use on where we look and how we walk when negotiating floor based obstacles. PLoS ONE 2017, 12. [CrossRef]

6. Youngjun, H.; Hasik, L. Big Data Analysis of Pedestrian Accicents in Seoul Using Deep Learning. Available online: https://www.si.re.kr/node/64143 (accessed on 31 August 2020).

7. Hyman, I.E.; Boss, S.M.; Wise, B.M.; McKenzie, K.E.; Caggiano, J.M. Did you see the unicycling clown? Inattentional blindness while walking and talking on a cell phone. Appl. Cogn. Psychol. 2010, 24, 597-607. [CrossRef]

8. Lamberg, E.M.; Muratori, L.M. Cell phones change the way we walk. Gait Posture 2012, 35, 688-690. [CrossRef]

9. Lopresti-Goodman, S.M.; Rivera, A.; Dressel, C. Practicing Safe Text: The Impact of Texting on Walking Behavior. Appl. Cogn. Psychol. 2012, 26, 644-648. [CrossRef]

10. Plummer, P.; Zukowski, L.A.; Giuliani, C.; Hall, A.M.; Zurakowski, D. Effects of Physical Exercise Interventions on Gait-Related Dual-Task Interference in Older Adults: A Systematic Review and Meta-Analysis. Gerontology 2015, 62, 94-117. [CrossRef] [PubMed]

11. Barkley, J.E.; Lepp, A. Cellular telephone use during free-living walking significantly reduces average walking speed. BMC Res. Notes 2016, 9, PMC4815203. [CrossRef] [PubMed]

12. Korea Telecome Corporation. The Begining of BigData Life Log: Analysis of Movining and Staying Patterns; KT Coporation: Seongnam, Korea, 2017.

13. VTPI Evaluating Active (Non-Motorized) Transpot: Techniques for Measuring Walking and Cycling Activity and Conditions. Available online: https://www.vtpi.org/tdm/tdm63.htm\#_Toc272910906 (accessed on 15 December 2018).

14. WalkScore Walk Score. Available online: https://www.walkscore.com/cities-and-neighborhoods/ (accessed on 26 October 2019).

15. Lo, R.H. Walkability: What is it? J. Urban. 2009, 2, 145-166. [CrossRef]

16. Saelens, B.E.; Handy, S.L. Built environment correlates of walking: A review. Med. Sci. Sports Exerc. 2008, 40, S550-S566. [CrossRef] [PubMed]

17. Franěk, M. Environmental factors influencing pedestrian walking speed. Percept. Mot. Skills 2013, 116, 992-1019. [CrossRef] [PubMed]

18. Franěk, M.; Režný, L.; Šefara, D.; Cabal, J. Effect of traffic noise and relaxations sounds on pedestrian walking speed. Int. J. Environ. Res. Public Health 2018, 15, 752. [CrossRef] [PubMed]

19. Dannenberg, A.L.; Cramer, T.W.; Gibson, C.J. Assessing the walkability of the workplace: A new audit tool. Am. J. Heal. Promot. 2005, 20, 39-44. [CrossRef] [PubMed]

20. Agrawal, A.W.; Schlossberg, M.; Irvin, K. How far, by which route and why? A spatial analysis of pedestrian preference. J. Urban Des. 2008, 13, 81-98. [CrossRef] 
21. Gallimore, J.M.; Brown, B.B.; Werner, C.M. Walking routes to school in new urban and suburban neighborhoods: An environmental walkability analysis of blocks and routes. J. Environ. Psychol. 2011, 31, 184-191. [CrossRef]

22. Hahm, Y.; Yoon, H.; Choi, Y. The effect of built environments on the walking and shopping behaviors of pedestrians; A study with GPS experiment in Sinchon retail district in Seoul, South Korea. Cities 2019, 89, 1-13. [CrossRef]

23. McCormack, G.R.; Giles-Corti, B.; Bulsara, M. The relationship between destination proximity, destination mix and physical activity behaviors. Prev. Med. 2008, 46, 33-40. [CrossRef]

24. Moudon, A.V.; Lee, C.; Cheadle, A.D.; Garvin, C.; Johnson, D.; Schmid, T.L.; Weathers, R.D.; Lin, L. Operational Definitions of Walkable Neighborhood: Theoretical and Empirical Insights. J. Phys. Act. Heal. 2006, 3, S99-S117. [CrossRef]

25. Spooner, D. Ten Minutes Wide: Human Walking Capacities and the Experiential Quality of Campus Design. Plan. High. Educ. 2011, 39, 11-22.

26. Joseph, A.; Zimring, C. Where active older adults walk: Understanding the factors related to path choice for walking among active retirement community residents. Environ. Behav. 2007, 39, 75-105. [CrossRef]

27. Pikora, T.J.; Bull, F.C.L.; Jamrozik, K.; Knuiman, M.; Giles-Corti, B.; Donovan, R.J. Developing a reliable audit instrument to measure the physical environment for physical activity. Am. J. Prev. Med. 2002, 23, 187-194. [CrossRef]

28. Alfonzo, M. To walk or not to walk. Environ. Behav. 2005, 161, 30. [CrossRef]

29. Brown, B.B.; Werner, C.M.; Amburgey, J.W.; Szalay, C. Walkable route perceptions and physical features: Converging evidence for en route walking experiences. Environ. Behav. 2007, 39, 34-61. [CrossRef]

30. Koohsari, M.J.; Kaczynski, A.T.; Giles-Corti, B.; Karakiewicz, J.A. Effects of access to public open spaces on walking: Is proximity enough? Landsc. Urban Plan. 2013, 117, 92-99. [CrossRef]

31. Maleki, M.Z.; Zain, M.F.M. Factors that influence distance to facilities in a sustainable efficient residential site design. Sustain. Cities Soc. 2011, 1, 236-243. [CrossRef]

32. Hahm, Y.; Yoon, H.; Jung, D.; Kwon, H. Do built environments affect pedestrians' choices of walking routes in retail districts? A study with GPS experiments in Hongdae retail district in Seoul, South Korea. Habitat Int. 2017, 70, 50-60. [CrossRef]

33. Haga, S.; Sano, A.; Sekine, Y.; Sato, H.; Yamaguchi, S.; Masuda, K. Effects of using a Smart Phone on Pedestrians' Attention and Walking. Procedia Manuf. 2015, 3, 2566-2573. [CrossRef]

34. Balsas, C.J.L. Sustainable transportation planning on college campuses. Transp. Policy 2003, 10, 35-49. [CrossRef]

35. International Sustainable Campus Network Best Practice in Campus Sustainability. Available online: https://www.international-sustainable-campus-network.org/downloads/general/374-2014-best-practicein-campus-sustainability/file (accessed on 15 November 2019).

36. Groat, L.; Wang, D. Architectural Research Methods, 2nd ed.; Wiley: New York, NY, USA, 2013; ISBN 978-0750658515.

37. Garling, T.; Book, A.; Lindberg, E. Cognitive Mapping of Large-Scale Environments. Environ. Behav. 1984, 16, 3-34. [CrossRef]

38. Rovine, M.J.; Weisman, G.D. Sketch-map variables as predictors of way-finding performance. J. Environ. Psychol. 1989, 9, 217-232. [CrossRef]

39. Wang, J.; Schwering, A. Invariant spatial information in sketch maps for sketch map alignment. J. Spat. Inf. Sci. 2015. Under review.

40. Bell, P.; Greene, T.; Fisher, J.; Baum, A. Environmental Psychology, 5th ed.; Psychology Press: Abingdon, OX, UK, 2005; ISBN 978-0805860887.

41. Lynch, K. The Image of the City; The MIT Press: Cambridge, MA, USA, 1960; ISBN 978-0-262-62001-7.

42. Snyder, J.C. Architectural Research; Van Nostrand Reinhold Company Inc.: New York, NY, USA, 1984; ISBN 0-442-28211-7.

43. Zeisel, J. Inquiry by Desing: Environment/Behavior/Neuroscience in Architecture, Interiors, Landscape, and Planning, 1st ed.; W. W. Norton \& Company, Inc.: New York, NY, USA, 2006; ISBN 0-393-73184-7.

44. USGBC LEED v4 for Neighborhood Development. Available online: https://www.usgbc.org/guide/nd (accessed on 7 July 2019). 
45. Gehl, J. Life Between Buildings: Using Public Space, 6th ed.; Island Press: Washington, DC, USA, 2011; ISBN 978-1597268271.

46. Whyte, W.H. The Social Life of Small Urban Spaces; Project for Public Spaces: New York, NY, USA, 2001; ISBN 978-0970632418.

47. Saaty, T.L. The analytic hierarchy process: What it is and how it is used. Math. Model. 1987, 9, 161-176. [CrossRef]

48. Yin, R.K. Case Study Research: Design and Methods, 6th ed.; SAGE Publications Inc.: Thousand Oaks, CA, USA, 2017; ISBN 9781506336169.

49. McCormack, G.R.; Cerin, E.; Leslie, E.; du Toit, L.; Owen, N. Objective versus perceived walking distances to destinations: Correspondence and predictive validity. Environ. Behav. 2008, 40, 401-425. [CrossRef]

50. Gebel, K.; Bauman, A.; Owen, N. Correlates of non-concordance between perceived and objective measures of walkability. Ann. Behav. Med. 2009, 37, 228-238. [CrossRef]

51. Gehl, J. Cities for People; Island Press: Washington, DC, USA, 2010; ISBN 978-1597265737.

52. Hoogendoorn, S.P.; Bovy, P.H.L. Pedestrian route-choice and activity scheduling theory and models. Transp. Res. Part. B Methodol. 2004, 38, 169-190. [CrossRef]

53. USGBC LEED v4.1 Building Design and Construction. Available online: https://www.usgbc.org/leed/v41\#bdc (accessed on 22 May 2019).

54. Sugiyama, T.; Leslie, E.; Giles-Corti, B.; Owen, N. Associations of neighbourhood greenness with physical and mental health: Do walking, social coherence and local social interaction explain the relationships? J. Epidemiol. Community Heal. 2008, 62, e9. [CrossRef]

55. Seoul Metropolitan Government New Traffic Signs for Smartphone Users. Available online: http://english. seoul.go.kr/new-traffic-signs-smartphone-users/ (accessed on 19 July 2019).

56. Holtzman, G. Community by design, by the people: Social approach to designing and planning cohousing and ecovillage communities. J. Green Build. 2014, 9, 60-82. [CrossRef]

Publisher's Note: MDPI stays neutral with regard to jurisdictional claims in published maps and institutional affiliations.

(C) 2020 by the authors. Licensee MDPI, Basel, Switzerland. This article is an open access article distributed under the terms and conditions of the Creative Commons Attribution (CC BY) license (http://creativecommons.org/licenses/by/4.0/). 